\title{
2
}

\section{Legal Overview}

\section{Sarah Craig and Karin Zwaan}

\section{Introduction}

Common rules on most aspects of the asylum process are in force in the European Union (EU), building on the international refugee protection regime. This so-called EU asylum acquis has resulted in a "Common European Asylum System (CEAS)". EU legislation states that the CEAS is to be based on a full and inclusive application of the $1951 \mathrm{UN}$ Geneva Convention relating to the Status of Refugees (Refugee Convention). The principle of non-refoulement-also included in the Refugee Conventionis the most important principle in asylum law and is laid down in several international legal instruments. ${ }^{1}$ This principle prohibits the forced direct or

\footnotetext{
${ }^{1}$ E.g. Article 33, UN Refugee Convention; Article 3, UN Convention against Torture; Article 7, UN International Covenant on Civil and Political Rights; Article 3, European Convention on Human Rights (ECHR); Article 19(2), EU Charter on Fundamental Rights; Article 21, QD1 and QDII; and Article 5, RD.
}

S. Craig $(\bowtie)$

University of Glasgow, Glasgow, Scotland

e-mail: sarah.craig@glasgow.ac.uk

K. Zwaan

Radboud University Nijmegen, Nijmegen, The Netherlands

e-mail:k.zwaan@jur.ru.nl 
indirect removal of a person to a country or territory where he $\mathrm{e}^{2}$ runs a risk of being subjected to severe human rights violations.

The CEAS consists of rules to determine which State is responsible for determining a claim; to define asylum seekers' entitlements and obligations as regards their reception in Member States; to regulate the asylum procedure itself; and to determine who qualifies for international protection.

Unlike the rest of the chapters in this volume, this chapter is not empirical, but sets out the legal framework for asylum determination in Europe. Its primary purpose is to offer a reflection on and some insight into the functioning of the CEAS, with a view to creating a legal background and framework for the ethnographic chapters that follow.

\section{International and European Law Framework}

The CEAS is a fundamental part of the EU's Area of Freedom, Security and Justice (AFSJ), and its aim is to establish a fair and efficient asylum system. The CEAS consists of a legal framework covering all aspects of the asylum process, and a support agency-the European Asylum Support Office (EASO). One must bear in mind that achieving the CEAS' twofold goal of efficiency and fairness is, from a human rights perspective, a task that creates internal contradictions, in the sense that implementing efficiency may rule out fairness, and promoting fairness requires an investment of time and effort which State authorities may discourage. The task of reconciling, in individual cases, the conflicts inherent in pursuing this twofold goal falls on decision-makers and judges (see, for example, the chapters by Kobelinsky, Hambly, Affolter et al., and Liodden, this volume). As demonstrated throughout this book, not only decision-makers, but a cast of other actors also have profound influences. The substantive chapters of this book provide perspectives on the conflicts inherent in asylum decision-making and on how the actors involved attempt to resolve them, but while most of the countries discussed here participate fully in the CEAS, not all do. Two Member States (UK and Denmark) exercise opt-outs in relation to certain CEAS measures, and another two are non-EU countries (Norway and Switzerland). However, all of the countries take part in the 'Dublin regime', and have other

\footnotetext{
${ }^{2}$ Early refugee law has been 'characterized by a complete blindness to women, gender, and issues of sexual inequality' (Edwards 2010: 23). We are aware that nowadays reference would be made to 'they' instead of 'he', but as this is a legal chapter for reasons of clarity we are using 'he' if the actual legal text uses 'he'.
} 
associations with the AFSJ. We therefore focus in this chapter on the CEAS, and on its contradictory aims and themes, because they flesh out the meaning, as well as the weakness, of international protection standards, and they also highlight the conflicts-between fairness and efficiency, and between protection and exclusion-which bedevil asylum decision-making processes in all of the countries covered here.

Since 1999, the CEAS has gone through two phases of legislation. The first culminated in 2005, and the second concluded in 2013. The first phase focused on harmonisation on the basis of common minimum standards, leading to the second, whose aim was the establishment of a single asylum procedure and a uniform status for those who are granted asylum throughout the EU, an aim which has not yet been achieved. Whereas some common EU rules in the asylum field take the form of directly binding 'Regulations', most take the form of 'Directives', which require Member States to achieve a particular result without dictating the means of achieving that result. Directives are usually transposed into national legislation. They therefore depend on national implementation for their effectiveness.

The protection of asylum seekers, refugees and those in need of subsidiary protection can be characterised as an interplay between several overlapping legal regimes. The main instruments are the 1951 UN Refugee Convention, the UN Convention against Torture, the UN Convention on Civil and Political Rights, EU law and the ECHR. ${ }^{3}$

Judicial scrutiny at the highest level is performed by the Court of Justice of the EU (CJEU), which has jurisdiction to consider requests for preliminary rulings from national courts, as well as dealing with appeals and other matters. The CJEU is tasked with examining the legality of EU measures, interpreting EU law, and ensuring its uniform application across the $28 \mathrm{EU}$ Member States. In the implementation of this last task, the CJEU relies on national courts to apply EU law uniformly in their respective jurisdictions, albeit under the supervision of the CJEU. The CJEU is first and foremost an important actor in the protection of human rights, drawing on them as fundamental principles of EU law, and ruling on how human rights standards should be interpreted across the Member States. This Court is not to be confused with the European Court of Human Rights (ECtHR), a permanent international court set up in 1959 with jurisdiction to rule on all matters concerning the interpretation and application of the ECHR; it specialises in

${ }^{3}$ Currently, all Member States have ratified the ECHR as well as several non-EU countries and even some non-European countries. 
the safeguarding of a minimum level of human rights protection among the ECHR's contracting parties. The ECtHR may receive applications from any person, group or non-governmental organisation claiming to be the victim of a violation of the rights set out in the ECHR by one of its state parties.

The terms used in European asylum law need some clarification. In daily life the terms 'migrant', 'asylum seeker' and 'refugee' are often used interchangeably, but they refer to different legal statuses. 'Migrant' is the general term for people who move from one region to another. This movement might be voluntary or because of economic hardship or other problems. ${ }^{4}$ The term 'asylum seeker' is used for someone who has left their country to seek international protection. In EU law, international protection takes two forms. In the first place, protection as a refugee: 'refugee' refers to a person who has fled their country and cannot return because of a well-founded fear of persecution due to their race, religion, nationality, membership of a particular social group or political opinion. ${ }^{5}$ In the second place, someone who has fled because they face serious harm ${ }^{6}$ may qualify for international protection. Serious harm may consist of: (a) the death penalty or execution; or (b) torture or inhuman or degrading treatment or punishment of an applicant in their country of origin; or (c) serious and individual threat to a civilian's life or person by reason of indiscriminate violence in situations of international or internal armed conflict.

Situations of armed conflict and violence frequently involve exposure to serious human rights violations or other serious harm amounting to persecution or serious harm. Such persecution/serious harm could include situations of genocide and ethnic cleansing; torture and other forms of inhuman or degrading treatment; rape and other forms of sexual violence; forced recruitment, including of children; arbitrary arrest and detention; hostage taking and enforced or arbitrary disappearances. In situations of armed conflict and violence a person may be at risk of being singled out or targeted for persecution or serious harm. Equally, in such situations, entire groups or populations may be at risk of persecution, leaving each member of the group at risk. The fact that many or all members of particular communities are at risk does not undermine the validity of any particular individual's claim. ${ }^{7}$

\footnotetext{
${ }^{4}$ See EASO Practical Guide Evidence assessment: https://www.easo.europa.eu/practical-tools.

${ }^{5}$ Article 1A(2) UN Refugee Convention.

'Article 15 QDII. The UK and Ireland opted into the CEAS' first phase instruments, which means that they are still bound by the original QD1 and APD1. Article 15 QDI is in similar terms.

${ }^{7}$ See UNHCR (2016, paras. 13 and 16).
} 
At the time of writing, the main CEAS legislation comprises the revised Dublin Regulation (Dublin III), the revised Eurodac Regulation, the Reception Conditions Directive (I or II), the Qualification Directive (I or II) and the Asylum Procedures Directive (I or II). Most of the countries whose national asylum systems provide the focus for the substantive chapters of this book participate in both phases of CEAS legislation but, as noted above, four do not. The UK chose to 'opt in' to the first phase of CEAS legislation, but then took a piecemeal approach, 'opting out' of the revised 'second phase' versions of the Reception Conditions Directive (II), Qualification Directive (II), and Asylum Procedures Directive (II), and 'opting in' to the revised Dublin Regulation (Dublin III) and the revised Eurodac Regulation (aka the Dublin system). Denmark has a long-standing 'opt-out' arrangement in relation to most CEAS measures but like the UK, it participates in the Dublin system. As already noted, Switzerland and Norway are non-EU states that participate in the Dublin system, and their position is, of course, of interest to the UK in the context of the June 2016 Brexit vote. Whether, as part of the Brexit negotiations, the UK would also seek to continue its participation in the Dublin system following its departure from the EU is something we can speculate about, especially given the UK's common interest with the rest of the EU in the security objectives of the Eurodac database, but nothing can be assumed.

The Dublin III Regulation establishes a hierarchy of criteria for identifying which EU Member State is responsible for examining an asylum seeker's claim for protection in Europe. To establish this responsibility the applicant is fingerprinted, and the information goes to the Eurodac database (Eurodac Regulation). The aim of the Dublin Regulation is to ensure that only one EU Member State is responsible for the examination of an asylum application (to deter multiple asylum claims), and to allow that State to be identified as quickly as possible. The Dublin regime permits Member States to rely on the principle of mutual trust and the presumption that all EU Member States are safe for all asylum seekers: its criteria therefore provide that most asylum seekers may be sent back to their state of entry. This leads to an unequal distribution of asylum seekers amongst EU Member States and to the Member States where most asylum seekers enter the EU, such as Greece and Italy, facing problems in managing the increasing numbers of asylum seekers arriving (Guild 2016; Costello and Mouzarakis 2014). The extreme suffering which the operation of the Dublin criteria has caused to individuals has led to landmark cases being decided by the ECtHR and the CJEU which recognised the failure of the mutual trust principle and of the presumption of safety in the Dublin regime. This case law has been codified in the Dublin 
III Regulation so that it is not possible to transfer an asylum seeker to the responsible Member State where 'there are substantial grounds for believing that there are systemic flaws in the asylum procedure and in the reception conditions for applicants in that Member State, resulting in a risk of inhuman or degrading treatment'. In these circumstances, the Member State that is prevented from transferring the asylum seeker must examine the application itself. ${ }^{8}$

The Reception Conditions Directive ${ }^{9}$ sets out common standards for reception conditions for asylum seekers and makes it clear that an asylum seeker is entitled to reception while their asylum claim is being determined. It sets out rules relating to housing, food, health care and employment, as well as detailed common rules governing the limited circumstances in which asylum seekers can be detained.

The Qualification Directive ${ }^{10}$ sets out the standards to establish whether third country nationals or stateless person $s^{11}$ should be granted international protection. It defines who may be a beneficiary of international protection and describes the content of that protection. International protection may be given in the form of two different statuses, namely refugee status or subsidiary protection status. ${ }^{12}$ Subsidiary protection aims to cover other forms of protection, as guaranteed by human rights treaties, such as the ECHR or the UN Convention against Torture. The Qualification Directive aims to harmonise eligibility criteria for international protection, and incorporates a series of rights for beneficiaries of international protection (protection against refoulement, residence permits, travel documents, access to employment, access to education, social welfare, healthcare, access to accommodation, access to integration facilities, as well as specific provisions for children and vulnerable persons). By defining and harmonising the guarantees in human rights treaties which all the countries discussed in this volume have signed up to, the Qualification Directive (QD) provides the tools for giving meaning to those guarantees.

\footnotetext{
${ }^{8}$ Article 3(2) Dublin III. This Article codifies the cases ECtHR 21 January 2011, no. 30696/09, M.S.S. v. Belgium and Greece and CJEU 21 December 2011, joined cases C-411/10 and C-493/10, N.S. and Others.

${ }^{9}$ RCDII. Denmark, and the UK are not bound by this Directive, but Ireland has opted into the RCDII (Recast Reception Conditions Directive). The UK is bound by the terms of RCDI.

${ }^{10} \mathrm{QDII}$. The UK and Ireland opted into the CEAS' first phase instruments, which means that they are still bound by the original QDI.

${ }^{11} \mathrm{~A}$ third country national is a national of a non-EU country.

${ }^{12}$ Article 2 QDII; Article 2 QD1.
} 
The standards to guarantee access to a fair and efficient asylum system are laid out in the Asylum Procedures Directive (APD). ${ }^{13}$ The asylum procedure is meant to establish whether a third country national should be granted international protection, and whether the asylum seeker is entitled to have his claim processed according to the procedural standards of the APD. The APD aims to ensure fair, quick and good quality asylum decisions, and also that asylum seekers with special needs (such as unaccompanied minors) receive the necessary support to make their claims. Other procedural rights include rights to a personal interview, to legal assistance, a right to appeal and the right to remain in the territory while an appeal is being determined. ${ }^{14}$

\section{The Asylum Procedure: Determining Refugee- Or Subsidiary Protection Status}

In EU asylum procedures the central question that must be answered is whether an asylum seeker is in need of international protection. EU law stipulates that a person qualifies for international protection if he or she is a refugee and thus fears persecution, or if they would be subjected to serious harm when returned to their country of origin. ${ }^{15}$ Protection entails-more than anything else-the prohibition of 'refoulement'. This prohibition is firmly rooted in international, ${ }^{16}$ European ${ }^{17}$ and $\mathrm{EU}^{18}$ law, and means that a state is prohibited from sending a person (back) to a place where they could be persecuted or risk serious harm. ${ }^{19}$ An applicant qualifies for international protection if they have a well-founded fear of being persecuted for reasons of race, religion, nationality, membership of a particular social group or political opinion in accordance with the 1951 Convention, or would face a real risk of suffering serious harm if returned to the country of origin or habitual residence. To determine an asylum application, evidence may be submitted

\footnotetext{
${ }^{13}$ APDII. The UK and Ireland opted into the CEAS' first phase instruments, which means that they are still bound by the original APD1.

${ }^{14}$ Articles 14, 22, 24, 46 QDII; Articles 12, 39 QD1.

${ }^{15}$ Article 4(3) QDII; Article 4(3) QD1.

${ }^{16}$ Article 33 Refugee Convention, Article 3 of the UN Convention against Torture, Article 7 UN International Covenant on Civil and Political Rights.

${ }^{17}$ Article 3 European Convention on Human Rights.

${ }^{18}$ Article 4 Charter of Fundamental Rights of the European Union.

${ }^{19}$ Article 15 QDII; Article 15 QDI.
} 
by an applicant to substantiate his or her application and may also be gathered by the determining authority through its own means. Evidence may include anything that asserts, confirms, supports, refutes or otherwise bears on the relevant facts in issue.

Article 8(2) APDI (Article 10(3) APDII) requires Member States to ensure that 'decisions by the determining authority on applications for asylum are taken after an appropriate examination'. To this end, Member States should ensure that applications are examined and decisions taken individually, objectively, and impartially. Article 9(2) APDI (Article 11(2) APDII) requires that, where an application is rejected, the reasons in fact and in law are stated in the decision. The obligation to state reasons for a decision that are sufficiently specific and concrete to allow the applicant to understand why his or her application has been rejected has been framed as a corollary of the fundamental EU law principle of the right to defence.

\section{Actors}

In the asylum procedure, where refugee status determination (RSD) and subsidiary protection status determination take place many 'actors' are involved. In this volume we see as main actors asylum seekers themselves (including unaccompanied minor asylum seekers; (Chapter 6), immigration officers and decision makers (Chapters 12-14), Home Office Presenting Officers (HOPOs; Chapter 5) judges (Chapter 3), interpreters (Chapter 7) and lawyers (Chapter 10). In principle, there is an even wider cast of 'actors' than this, including clerks, security staff, witnesses, MacKenzie friends, observers of the case such as media and researchers.

Legal texts on refugee law define actors differently. From the legal perspective, we think of 'actors of persecution or serious harm' and 'actors of protection'. Actors of persecution or serious harm include: (a) the State; (b) parties or organisations controlling the State or a substantial part of the territory of the State; and (c) non-State actors, if it can be demonstrated that the state and international organisations, are unable or unwilling to provide protection against persecution or serious harm. ${ }^{20}$ Actors of protection, protect against persecution or serious harm. These can be: (a) the State; or (b) parties or organisations, including international organisations, controlling

${ }^{20}$ Article 6 QDII; Article 6 QD1. 
the State or a substantial part of the territory of the State; provided they are willing and able to offer protection. ${ }^{21}$

With regard to the actors in the chapters of this volume, some definitions, as well as guidance about their role and treatment are also to be found in the CEAS. Article 2(l) QDII defines an 'unaccompanied minor' as a minor who arrives on the territory of the Member State unaccompanied by an adult responsible for them whether by law or by the practice of the Member State concerned, and for as long as they are not effectively taken into the care of such a person; that includes a minor who is left unaccompanied after they have entered the territory of the Member State. Also in the APD special rules apply to asylum seeking children, and it should be borne in mind that according to preamble (33) to the APD, the best interests of the child should be a primary consideration of Member States when applying the APD, in accordance with the Charter of Fundamental Rights of the European Union and the 1989 United Nations Convention on the Rights of the Child. In assessing the best interest of the child, Member States should in particular take due account of the minor's well-being and social development, including their background.

With regard to immigration officers and decision makers, para. (16) of the preamble to the APD states that:

It is essential that decisions on all applications for international protection be taken on the basis of the facts and, in the first instance, by authorities whose personnel has the appropriate knowledge or has received the necessary training in the field of international protection.

And in relation to HOPOs (Chapter 5), who represent the UK's Home Office at appeal hearings, para. (17) of the APD's preamble states 'In order to ensure that applications for international protection are examined and decisions thereon are taken objectively and impartially, it is necessary that professionals acting in the framework of the procedures provided for in this Directive perform their activities with due respect for the applicable deontological principles'.

The central role of judges is recognised in Article 46 APDII concerning the right to an effective remedy for challenging a negative decision. ${ }^{22}$ Even in areas where common standards apply, there is need for judicial scrutiny

\footnotetext{
${ }^{21}$ Article 7 QDII; Article 7 QDI.

${ }^{22}$ Article 39 APDI.
} 
of first instance decisions. In 2015 Hungary recognised only $10 \%$ of its asylum seekers as needing protection. The figure in Germany was $40 \%$ and it reached $65 \%$ in Italy. The differences regarding refugees from Iraq were particularly extreme. On the EU average, one in two was considered worthy of protection, in Italy almost all and in Greece only 3\%-in spite of the fact that all follow the same European law. European courts have highlighted, and even heightened, the contrasting situations in different Member States. For instance, ever since the ECtHR in 2011 cited grave shortcomings in the Greek asylum process, and declared the living conditions of refugees there to be 'inhumane' (see also Giannopoulou and Gill, this volume), Germany has not sent any asylum seekers back to Greece. ${ }^{23}$ Nor is Italy necessarily a secure third country. At the end of 2014, the human rights court decreed that the Swiss-ordered deportation of an eight-member family from Afghanistan was 'inhumane treatment'-because no assurance could be received from Italy that the children would be housed in a manner suitable to their age and that the family could remain together. ${ }^{24}$

\section{Communication}

The UNHCR Handbook is the authoritative source of guidance for government decision makers, and it acknowledges that some asylum seekers might be reticent with officials due to their experiences in their home country. Many are tired, anxious or feel inhibited during the interview. ${ }^{25}$

Communication in asylum interviews is different from everyday conversation due to at least three factors (Doornbos 2005). First, the interlocutors often do not speak the same language (van der Kleij 2015: 253). In the vast majority of cases, the officer conducts the interview with the assistance of an interpreter, employed by the Ministry of Justice, Border Agency, etc., on a sessional basis. Secondly, communication in asylum cases is a form of intercultural communication (Kälin 1986: 23). Thirdly, communication in asylum cases is a form of institutional interaction: communication within a strictly organised, often bureaucratic context (Drew and Heritage 1992). The CEAS framework acknowledges that the asylum process needs

\footnotetext{
${ }^{23}$ Judgment of the ECtHR 21 January 2011, Application no. 30696/09, M.S.S. v. Belgium and Greece. and CJEU 21 December 2011, joined cases C-411/10 and C-493/10, N.S. and Others.

${ }^{24}$ ECtHR 4 November 2014, Application no. 29217/12, Tarakhel. See also: http://www.zeit.de/ gesellschaft/2016-03/european-asylum-law-refugees-turkey/seite-2.

${ }^{25}$ Para. 198 and 199 UNHCR Handbook.
} 
to provide a context within which communication is possible, but it takes a pragmatic approach. Preamble (25) APDII provides that 'every applicant should have $[\ldots]$ the opportunity to cooperate and effectively communicate with the competent authorities so as to present the relevant facts of his or her case'. Expanding on this, Article 12 APDII specifies that providing the services of an interpreter is a basic guarantee for asylum applicants when submitting their case to the competent authorities, and Article 14 requires the competent authorities to:

select an interpreter who is able to ensure appropriate communication between the applicant and the person who conducts the interview, in a language preferred by the applicant, unless there is another language which he or she understands and in which he or she is able to communicate clearly. ${ }^{26}$

Throughout this volume, and particularly in Part II, perspectives on communication build on the linguistic, cross-cultural and bureaucratic issues referred to above, and consider in detail the influence which the actors involved have on the process. They examine the provision of interpretation, the interviewing and decision-making processes, etc., and they reflect on the roles of the interpreter, applicant, decision maker, lawyer and other actors who influence the process in formal and informal ways. The interpreter's active role in communicating between applicant and decision-maker, and the implications of their ability, through their omissions and interventions, to influence the fairness (or otherwise) of the outcome of the claim come in for particular attention. These chapters capture the challenges posed to the asylum process by cross-cultural communication, and they also bring out the essentially narrative and communicative nature of the asylum process (Zahle 2005). The pragmatic approach to communication which the procedural rules of the APD take-requiring provision of an interpreter capable of ensuring 'appropriate communication'-struggles to embrace the complex communication needs that accompany the recounting of traumatic personal experiences, and as these chapters show, the rules rely heavily on the behaviour of individual interpreters and decision-makers.

\footnotetext{
${ }^{26}$ Reasonable requests that the interpreter be of the same gender as the applicant should also be complied with, and interviews with minors should be conducted in a child appropriate manner (Article 14 APDII).
} 


\section{Decision Making}

Being recognised as a refugee or receiving subsidiary protection is vitally dependent on the legal or administrative process by which governments determine protection claims. In relation to the decision-making process, the UNHCR handbook states:

It should be recalled that an applicant for refugee status is normally in a particularly vulnerable situation. He finds himself in an alien environment and may experience serious difficulties, technical and psychological, in submitting his case to the authorities of a foreign country, often in a language not his own. His application should therefore be examined within the framework of specially established procedures by qualified personnel having the necessary knowledge and experience, and an understanding of an applicant's particular difficulties and needs. (UNHCR 2011, para. 190)

The ECtHR has held that individuals need access to the asylum procedure as well as adequate information concerning the procedure to be followed. The authorities are also required to avoid excessively long delays in deciding asylum claims. In assessing the effectiveness of examining first instance asylum claims, the ECtHR has also considered other factors, such as the availability of interpreters, access to legal aid and the existence of a reliable system of communication with asylum seekers. ${ }^{27}$

\section{Standard and Burden of Proof}

The effectiveness of the right to asylum and to be protected against refoulement would be undermined if States placed too heavy a burden on applicants of establishing a well-founded fear of persecution or serious harm. As regards the standard of proof, the asylum seeker is expected to show that there is a 'reasonable degree of likelihood' of future persecution or that there are substantial grounds for believing that they face a real risk of serious harm. This standard is relatively relaxed: it is far lower than the criminal law standard, and even the usual civil law standard, and this suggests that proving an asylum claim should be comparatively straightforward.

\footnotetext{
${ }^{27}$ ECtHR 21 January 2011, Application no. 30696/09, M.S.S. vs. Belgium and Greece, para. 293.
} 
Understanding why it is not straightforward requires us to consider in some detail what is involved in substantiating an asylum claim.

States are afforded extensive discretion when laying down the rules for asylum procedures regarding the burden and standard of proof. As regards the burden of proof, this is placed on the asylum seeker. Usually states expect asylum seekers to adduce evidence in order to substantiate their asylum claim. For many asylum seekers, it is difficult to obtain such evidence.

States will take into account different forms of evidence-including documents and other evidence-concerning the position and personal circumstances of the applicant: their nationality; the reasons for applying for asylum, including previous persecution; the situation in the country of origin; the applicant's activities in the country of refuge; and the availability of safe third countries. Medical reports, country of origin information (COI) and language analysis are also relevant in this framework.

\section{Evidentiary Assessment}

Evidentiary assessment can be defined as the primary method of establishing the facts of an individual case through the process of examining and comparing available pieces of evidence. The assessment of evidence is, in general, not regulated by international law (UNHCR 2013). The 1951 Refugee Convention does not provide for any specific provisions dealing with evidentiary assessment. Some guidance has, however, been developed in the field both in the form of the UNHCR Handbook (UNHCR 2011, see above) and in the UNHCR Note on Burden and Standard of Proof in Refugee Claims (UNHCR 1998).

As regards the assessment of evidence, the Qualification Directive constitutes the first legally binding supranational instrument of regional scope establishing what criteria the applicant needs to meet in order to qualify for international protection. The Qualification Directive relies to a large extent on international and European refugee and human rights instruments and jurisprudence.

European countries have different legal traditions and varying practices regarding evidentiary assessment. If Member States apply similar legal concepts on eligibility for international protection, but their treatment of the evidence is different, they may reach different conclusions. Asylum procedures are different from other legal procedures, due partly to the serious consequences of the decision taken, and partly to the lack of the usual means of establishing objective evidence. In most cases the asylum narrative is the 
main source of evidence, whereas in other types of case, there are likely to be other witnesses who can support or call into question aspects of the claimant's account. Therefore, establishing requirements for specific procedural norms for the assessment of evidence and the knowledge of these standards are essential for a fair and effective asylum decision-making process. ${ }^{28}$ As a result, the Qualification Directive not only defines what a refugee or person needing subsidiary protection is, but it also establishes procedural norms for the assessment of evidence in asylum claims.

\section{Procedural Norms for the Assessment of Evidence (Article 4 QDI; QDII)}

Article 4 QDII $^{29}$ addresses the assessment of facts and circumstances with regard to qualification for both refugee and subsidiary protection status. Article 4(1) QDII, together with Article 4(2) QDII, stipulates that it is the duty of the Member State to assess the relevant elements of the application in cooperation with the applicant. Article 4(2) QDII lists the relevant elements required for the substantiation of an application for international protection. These consist of the applicant's statements and all the documentation at the applicant's disposal regarding his age, background (including that of relevant relatives), identity, nationality (ies), country (ies) and place(s) of previous residence, previous asylum applications, travel routes, travel documents, and the reasons for applying for international protection. Article 4(3) QDII states that the assessment of an application should be carried out on an individual basis and lists non-exhaustively some of the factors that should be taken into account. Moreover, Article 4(5) QDII states that where aspects of the applicant's statements are not supported by documentary or other evidence, those aspects shall not need confirmation when five stipulated conditions are met. ${ }^{30}$ These conditions are:

\footnotetext{
${ }^{28}$ See also EASO (2015).

${ }^{29}$ The text of Article 4 is the same for QD1 and QDII, but here we refer to QDII.

${ }^{30}$ The terms of Article 4 QDI are the same as Article 4 QDII, and therefore, the same measures apply in the UK. UK Immigration Rules say that confirmation of the person's statements will not be needed (when the five conditions in Article 4(5) QDI noted above) are met: Immigration Rules Part 11 Asylum: Rule 339L. (339 N 'In determining whether the general credibility of the person has been established the Secretary of State will apply the provisions in 5.8 of the Asylum and Immigration (Treatment of Claimants, etc.) Act 2004.').
} 
a. the applicant has made a genuine effort to substantiate his application;

b. all relevant elements at the applicant's disposal have been submitted, and a satisfactory explanation has been given regarding any lack of other relevant elements;

c. the applicant's statements are found to be coherent and plausible and do not run counter to available specific and general information relevant to the applicant's case;

d. the applicant has applied for international protection at the earliest possible time, unless the applicant can demonstrate good reason for not having done so; and

e. the general credibility of the applicant has been established.

This provision is intended as a 'translation' of the 'benefit of the doubt' idea. The principle of the benefit of the doubt recognises the considerable difficulties that applicants and decision-makers face gathering evidence to support the claim, and that there may still be some doubt regarding the facts. ${ }^{31}$ As the UNHCR Handbook puts it:

After the applicant has made a genuine effort to substantiate his story there may still be a lack of evidence for some of his statements. [...] It is hardly possible for a refugee to 'prove' every part of his case and, indeed, if this were a requirement the majority of refugees would not be recognised. It is therefore frequently necessary to give the applicant the benefit of the doubt. (Para. 203)

To sum up, the principle means that, when the conditions in QD Article 4(5) are met, corroboration (confirmation) of the applicant's own statements are not required in order to 'substantiate' (prove) their claim for international protection.

\section{Credibility Assessment}

The consequence of recognising that the applicant's statements can be sufficient to establish an asylum claim is that the outcome of the claim frequently turns on the credibility of those statements. UNHCR, in the exercise of its supervisory responsibility in relation to refugee protection,

${ }^{31}$ UNHCR Handbook para. 203. 
has produced guidance relevant to the assessment of credibility (UNHCR 2013), but neither the APD nor the QD explicitly or comprehensively prescribes how credibility assessment should be carried out.

So, although the international and European legal framework establishes principles and standards, it provides no predetermined structured approach for the assessment of credibility. A national approach therefore will and may be based on free evaluation of the evidence. As the substantive chapters show, the experience of asylum seekers is often that reliance on credibility does not work to their benefit, in the positive way that the benefit of the doubt principle, as discussed by Zahle (2005), suggested that it could. Instead, it works against them, and they meet a 'culture of disbelief' (see Kobelinsky, Hambly, Affolter et al, Schneider this volume).

\section{Article 4(2) the Duty to Co-operate}

The CJEU has—in a preliminary ruling-clarified the scope of application of the duty to cooperate in Article 4(2) QD. First, the court states that the assessment of facts and circumstances takes place in two separate stages. The first stage concerns the establishment of factual circumstances which may constitute evidence that supports the application, and the second stage relates to the legal appraisal of that evidence, which entails deciding whether there is a need for international protection. ${ }^{32}$ The Member State's duty to cooperate with the applicant, according to the CJEU, is only applicable to the first stage, when the facts and circumstances are being established, and can therefore be understood as the duty to cooperate to assemble all relevant evidence that supports the application, or to cooperate with the applicant as he takes on the burden of proving the case. Cooperation does not extend to the task of assessing whether the applicant has shown that a real risk of persecution or serious harm on return exists, or that $s /$ he has discharged that burden to the required standard of proof. ${ }^{33}$ According to the CJEU the duty to cooperate means, in practical terms, that if, for any reason whatsoever,

\footnotetext{
${ }^{32}$ CJEU 22 November 2012, C-277/11, M.M. para. 64.

${ }^{33}$ 'Not needing confirmation' suggests a relaxed burden of proof and 'cooperation' suggests a relaxed standard of proof for asylum processes compared with civil and criminal processes. 'Substantiation' therefore incorporates both the burden and the standard of proof since a claim will be substantiated if the applicant discharges the burden of proof by providing evidence to the standard required.
} 
the elements provided by an applicant for international protection are not complete, up to date or relevant, it is necessary for the Member State concerned to cooperate actively with the applicant, at that stage of the procedure, so that all the elements needed to substantiate the application may be assembled.

The CJEU judgment is a reminder that according to the case law of the ECtHR and in international refugee law the burden of assembling all relevant information for an application does not fall exclusively upon the applicant, but is shared with the government. ${ }^{34}$ The bureaucratic setting of asylum decision-making does not encourage cooperation, and it is unusual to expect decision makers to cooperate with evidence-gathering, as asylum decision makers are expected to do, in case such cooperation interferes with the decision maker's adjudicative role. That is why the duty to cooperate does not extend to the legal appraisal of the evidence, and the decision maker's consideration of whether, according to the standard of proof, the claim has been substantiated. There are indications in some of the chapters below of the struggles that decision-makers face as they attempt to reach a balance between cooperating with the applicant and practising the 'organised detachment' that their bureaucratic setting demands (see for example Schneider, this volume), and even national courts have placed limits on the scope of duty to cooperate. ${ }^{35}$

\section{Judicial Remedies}

Judicial protection is a crucial safeguard for asylum seekers. At the European level, judicial remedies are provided by the Court of Justice of the European Union (CJEU) and the ECtHR. In the absence of an international judicial remedy that States are prepared to use, and bearing in mind that the provision of the Refugee Convention permitting States to refer disputes to the International Court of Justice has never been invoked, ${ }^{36}$ the CJEU plays a crucial role in interpreting EU asylum law. This interpreting role may

\footnotetext{
${ }^{34}$ See also UNHCR Handbook, para. 196.

${ }^{35}$ TN(Afghanistan) [2015]UKSC 40, [73]; MJ(Afghanistan) [2013] UKUT 253(IAC).

${ }^{36}$ Refugee Convention Article 38.
} 
directly or indirectly define the standards for EU Member States (Garlick 2015: 108). But while European-level remedies contribute to the development of refugee law, they remain remote from the experience of most asylum seekers, since they usually come into play only where a case raises an aspect of EU refugee law that requires clarification, or after national remedies have been exhausted. Unsurprisingly, then, these 'high level' remedies are not addressed by any of the authors here, whose research focusses on the national level, where the roles of the state representative (Campbell, this volume), of the asylum advocate (Hambly, this volume) and of the judge (Sorgoni, this volume) are examined.

The EU system of judicial protection is based on the principle that all individuals are entitled to effective judicial protection of the rights they derive from the EU legal order. Judicial remedies in asylum cases are therefore a matter for the national courts of the Member States (Boeles et al. 2014: 411). At the national level, access to an effective remedy to challenge a negative decision must be available (Article 46 APDII; Article 39 APDI). The ECtHR has held that, in order to be effective, the appeal must be 'suspensive', meaning that appellants must be permitted to remain on the territory pending the outcome of their appeal. ${ }^{37}$ The scope of an appeal should permit a full review (APDII Article 46), allowing not only conclusions on the law but also factual conclusions, including about credibility, to be reviewed. Further evidence can also be submitted, such as independent expert reports about the appellant's linguistic background, where the state authorities have used in-house linguistic analysis to cast doubt on this (Zwaan 2010). Information on how to appeal, details of time limits, etc., should accompany a negative decision (APDI Article 9), and appellants should also receive legal advice and interpretation services (Article 39 APDI: Article 46 APDII). As the chapters below illustrate, however, the above safeguards do not of themselves ensure effective access to the appeal right in practice, and inadequate legal representation (or none at all), poor interpretation, battle-weary judges, aggressive State representatives and the formality and technicality of the procedures can present asylum appellants with insurmountable barriers rather than access to justice. Despite these obstacles, success rates at appeal frequently run at between 20 and 30\% (see Gill and Good, Kobelinsky, Campbell, Hambly, Sorgoni, all this volume; Liodden, this volume, reports a lower proportion in Norway), indicating how

${ }^{37}$ Gebremedhin v France 25389/05, ECtHR, 26 April 2007; Abdolkhani and Karimnia v. Turkey 30471/08, ECtHR, 22 September 2009. 
important the right to appeal safeguard is for refugee protection, as well as its potential.

\section{Final Remarks}

European Union Law has many parents and foster parents (Koopmans 1991: 506), and these parents and foster parents are firmly rooted in the legal traditions of the Member States. Almost all European asylum decisions stay within national legal systems, never reaching the lofty heights of the CJEU or the ECtHR. This means that, although we now have the European Union's CEAS, national legal traditions retain considerable influence over asylum processes. We do not have space here to explore the impact which the different European legal traditions have on asylum processes, or their relationship with legal integration (Bobek 2013), but we have taken as a point of departure the legal origins approach, because we see it as an approach which looks for the correlations between legal traditions (Nicola 2016: 869). There are many correlations between the asylum systems discussed in this volume, but three deserve emphasis. First, of course, there is the correlation between the human rights standards which bind all the states studied here, and their translation into CEAS measures, as seen in the Qualification Directive Article 4 on the burden of proof to be applied in national asylum processes. Secondly, correlations of concern about national security and sovereignty are also present in asylum systems. Mechanisms to address security issues can be found in refugee law itself, and the fingerprint and other personal data collected under the EURODAC Regulation also address Member States' security concerns, as does the CEAS' home within the EU's Area of Freedom Security and Justice. This can lead to a situation where judges, rather than presenting a challenge to State authorities, might be just as likely to be discussing the merits of deferring to them, particularly where there is a climate of insecurity (Harvey 2005). At the same time, the realities of refugee status determination across Europe reflect a collective failure on the part of Member States to work in solidarity to protect refugees (Campesi 2018). This leads us to the third and final correlation. This final correlation is also the most hopeful, as it is the one between the "legality principle" - of respect for the individual and the protection of the person in 
the determination of asylum cases (Harvey 2005), and the evidence in this volume's ethnographic chapters of "legal consciousness", in the sense of there being actors involved in all of the asylum processes studied here who continue to struggle with concepts of justice and fairness in their routine experiences and perceptions of law in their everyday lives (Merry 1990; Cowan 2004). Long may they continue to struggle with those concepts.

\section{References}

Bobek, M. (2013). Of Feasibility and Silent Elephants: The Legitimacy of the Court of Justice through the Eyes of National Courts. In M. a.o. Adams (Eds.), Judging Europe's Judges. London: Bloomsbury.

Boeles, P., den Heijer, M., Lodder, G., \& Wouters, K. (2014). European Migration Law (2nd ed.). Antwerp: Intersentia.

Campesi, G. (2018). Seeking Asylum in Times of Crisis: Reception, Confinement and Detention at Europe's Southern Borders. Refugee Survey Quarterly, 37(1), 44-70.

Costello, C., \& Mouzarakis, M. (2014). Reflections on Reading Tarakhel. Asiel en Migrantenrecht, 10, 404-411.

Cowan, D. (2004). Legal Consciousness: Some Observations. Modern Law Review, 67(6), 928-958.

Doornbos, N. (2005). On Being Heard in Asylum Cases: Evidentiary Assessment Through Asylum Interviews. In G. Noll (Ed.), Proof: Evidentiary Assessment and Credibility in Asylum Procedures. Leiden-Boston: Martinus Nijhoff Publishers.

Drew, P., \& Heritage, J. (Eds.). (1992). Talk at Work. Interaction in Institutional Settings. New York: Cambridge University Press.

EASO. (2015). EASO Practical Guide: Evidence Assessment. Available at: https:// www.easo.europa.eu/practical-tools.

Edwards, A. (2010). Transitioning Gender: Feminist Engagement with International Refugee Law and Policy 1950-2010. Refugee Survey Quarterly, 29(2), 21-45.

Garlick, M. (2015). International Protection in Court: The Asylum Jurisprudence of the Court of Justice of the EU and UNHCR. Refugee Survey Quarterly, 34, $107-130$.

Guild, E. (2016). Does the EU Need a European Migration and Protection Agency? International Journal of Refugee Law, 28(4), 585-600.

Harvey, C. (2005). Judging Asylum. In P. Shah (Ed.), The Challenge of Asylum to Legal Systems. London: Cavendish. 
Kälin, W. (1986). Troubled Communication: Cross-Cultural Misunderstandings in the Asylum-Hearing. International Migration Review, 20(2), 230.

Koopmans, T. (1991). The Birth of European Law at the Cross Roads of Legal Traditions. American Journal of Comparative Law, 39(3), 493-507.

Merry, S. E. (1990). Getting Justice and Getting Even: Legal Consciousness Among Working-Class Americans. Chicago: Chicago Press.

Nicola, F. G. (2016). National Legal Tradition at Work in the Jurisprudence of the Court of Justice of the European Union. American Journal of Comparative Law, 64(3), 865-890.

UN High Commissioner for Refugees (UNHCR). (1998, December 16). Note on Burden and Standard of Proof in Refugee Claims. Available at: http://www.refworld.org/docid/3ae6b3338.html. Accessed 18 June 2018.

UNHCR. (2011). Handbook and Guidelines on Procedures and Criteria for Determining Refugee Status Under the 1951 Convention and the 1967 Protocol Relating to the Status of Refugees.

UNHCR. (2013). Beyond Proof. Credibility Assessment in EU Asylum Systems. Brussels.

UNHCR. (2016). Guidelines on International Protection No. 12. Guidelines on International Protection pursuant to its mandate, as contained in par. 8(a) of the Statute of the Office of the United Nations High Commissioner for Refugees.

van der Kleij, S. (2015). Interaction in Dutch Asylum Interviews: A Corpus Study of Interpreter-Mediated Institutional Discourse. Utrecht: LOT Publishing.

Zahle, H. (2005). Competing Patterns for Evidentiary Assessments. In Noll, G. (Ed.), Proof, Evidentiary Assessment and Credibility in Asylum Procedures (pp. 13-27). The Netherlands: Brill.

Zwaan, K., Verrips, M., \& Muysken, P. (Eds.). (2010). Language and Origin: The Role of Language in European Asylum Procedures: Linguistic and Legal Perspectives. The Netherlands: Wolf Legal Publishers.

\section{Legal Documents}

APDI. (2005). Council Directive 2005/85/EC of 1 December 2005 on minimum standards on procedures in Member States for granting and withdrawing refugee status, OJ 2005, L 326, p. 13.

APDII. (2013). Council Directive 2013/32/EU of 26 June 2013 on common procedures for granting and withdrawing international protection (recast), OJ 2013, L 180, p. 60.

CJEU. (2003). Dublin I Council Regulation 343/2003/EC of 18 February 2003 establishing the criteria and mechanisms for determining the Member State 
responsible for examining an asylum application lodged in one of the Member States by a third-country national, OJ 2003, L 50, p. 1 .

Dublin III. (2013). Regulation (EU) No. 604/2013 of 26 June 2013 establishing the criteria and mechanisms for determining the Member State responsible for examining an application for international protection lodged in one of the Member States by a third-country national or a stateless person (recast) (Dublin III Regulation), OJ 2013, L 180, p. 31.

ECHR (European Convention on Human Rights and Fundamental Freedoms). As amended by Protocols Nos. 11 and 14 supplemented by Protocols Nos. 1, 4, 6, 7, 12 and 1.

Eurodac Regulation 603/2013/EU of 26 June 2013 on the establishment of Eurodac for the comparison of fingerprints for the effective application of Regulation (EU) No 604/2013 establishing the criteria and mechanisms for determining the Member State responsible for examining an application for international protection lodged in one of the Member States by a third-country national or a stateless person and on requests for the comparison with Eurodac data by Member States' law enforcement authorities and Europol for law enforcement purposes, and amending Regulation (EU) No 1077/2011 establishing a European Agency for the operational management of large-scale IT systems in the area of freedom, security and justice (recast), OJ 2013, L 180, pp. 1.

RCDI Council Directive 2003/9/EC of 27 January 2003 laying down minimum standards for the reception of asylum seekers, OJ 2003, L 31, p. 18.

RCDII. (2013). Reception Conditions Directive 2013/33/EU of 26 June 2013 laying down standards for the reception of applicants for international protection (recast), OJ 2013, L 180, p. 96.

RD Directive 2008/115/EC of the European Parliament and of the Council of 16 December 2008 on common standards and procedures in Member States for returning illegally staying third-country nationals, OJ 2008, L 348, p. 98.

Refugee Convention relating to the Status of Refugees. (1951). United Nations General Assembly resolution 429(V) of 14 December 1950, as amended by the 1967 Protocol.

QDI. (2004). Council Directive 2004/83/EC of 29 April 2004 on minimum standards for the qualification and status of third country nationals or stateless persons as refugees or as persons who otherwise need international protection and the content of the protection granted, OJ 2004, L 304, p. 12.

QDII. (2011). Council Directive 2011/95/EU of 13 December 2011 on standards for the qualification of third-country nationals or stateless persons as beneficiaries of international protection, for a uniform status for refugees or for persons eligible for subsidiary protection, and for the content of the protection granted (recast) OJ 2011, L 337, p. 9. 


\section{Case Law}

CJEU 21 December 2011, joined cases C-411/10 and C-493/10, N.S. and Others. CJEU 22 November 2012, C-277/11, M.M.

ECtHR 21 January 2011, Application no. 30696/09, M.S.S. vs. Belgium and Greece.

ECtHR 4 November 2014, Application no. 29217/12, Tarakhel.

Open Access This chapter is distributed under the terms of the Creative Commons Attribution 4.0 International License (http://creativecommons.org/licenses/ by/4.0/), which permits use, duplication, adaptation, distribution and reproduction in any medium or format, as long as you give appropriate credit to the original author(s) and the source, a link is provided to the Creative Commons license and any changes made are indicated.

The images or other third party material in this chapter are included in the work's Creative Commons license, unless indicated otherwise in the credit line; if such material is not included in the work's Creative Commons license and the respective action is not permitted by statutory regulation, users will need to obtain permission from the license holder to duplicate, adapt or reproduce the material. 